\title{
EVALUASI PROSES PENGEMBANGAN DAN PENERAPAN CLINICAL PATHWAY KASUS STROKE ISKEMIK AKUT DI RUMAH SAKIT ANUTAPURA KOTA PALU
}

\author{
Diah Mutiarasari ${ }^{1}$, Rizaldy Taslim Pinzon ${ }^{2}$, Gunadi $^{3}$ \\ ${ }^{1}$ Program Pascasarjana Fakultas Kedokteran Universitas Gadjah Mada \\ ${ }^{2}$ Bagian Saraf Fakultas Kedokteran Universitas Kristen Duta Wacana \\ 3Bagian Bedah Anak Fakultas Kedokteran Universitas Gadjah Mada
}

Korespondensi:ms.diah@yahoo.com

\begin{abstract}
ABSTRAK
Latar belakang: Stroke memiliki angka kematian dan kecacatan yang tinggi. Stroke menjadi penyebab nomor 1 admisi pasien ke rumah sakit. Penggunaan clinical pathway dapat mengurangi variasi dalam tindakan medis untuk kondisi klinis yang sama sehingga meningkatkan kualitas pelayanan stroke. Penelitian mengenai pengembangan clinical pathway sesuai Integrated Clinical Pathway Appraisal Tools (ICPAT) di Indonesia masih sangat terbatas.

Tujuan: Penelitian ini bertujuan mengevaluasi proses pengembangan dan penerapan clinical pathway kasus stroke iskemik akut di RS Anutapura Kota Palu.

Metode: Rancangan Penelitian ini adalah action research. Pengumpulan data dilakukan dengan triangulasi metode melalui wawancara terstruktur, diskusi kelompok terarah, survei, observasi, dan telaah dokumen. Integrated Clinical Pathway Appraisal Tools (ICPAT) digunakan sebagai alat ukur. Subyek penelitian sebanyak 25 responden terdiri dari petugas kesehatan RS Anutapura dan tim clinical pathway, 1 responden keluarga pasien dan 30 responden pasien yang dirawat inap di bagian saraf RS Anutapura yang memenuhi kriteria eligibilitas.

Hasil: Pada proses pengembangan hasil evaluasi dengan ICPAT menunjukkan dimensi 1 terpenuhi persyaratan secara keseluruhan. Dimensi 1 memberikan kepastian bahwa dokumen yang dikembangkan merupakan clinical pathway. Pada proses penerapan clinical pathway dilakukan evaluasi uji coba clinical pathway stroke iskemik akut sejak pasien masuk RS sampai pasien diijinkan keluar RS. Indikator proses pelayanan yang dinilai adalah pemeriksaan EKG sebesar 100\%, penilaian kemampuan menelan sebesar $100 \%$, pemberian antiplatelet (aspirin 80mg atau clopidogrel $75 \mathrm{mg}$ ) diberikan 24-48 jam sejak masuk RS sebesar 100\%, pemberian anti platelet (aspirin $325 \mathrm{mg}$ atau clopidogrel 300mg) diberikan 24-48 jam sejak masuk RS sebesar 46,7 \% dan penilaian status gizi dan diet seawal mungkin sebesar 100\%. Kepatuhan pengisian clinical pathway dokter dan case manager mencapai $80 \%$.

Kesimpulan: Berdasarkan evaluasi $\mathrm{CP}$ baru stroke iskemik akut menunjukkan kesesuaian dengan ICPAT. Sinergi seluruh manajemen RS, clinical champion, dokter spesialis saraf dan tim multidisiplin menjadi kunci keberhasilan pengembangan dan penerapan clinical pathway.
\end{abstract}

Kata Kunci: clinical pathway, ICPAT, stroke, action research. 


\title{
CLINICAL PATHWAY IMPLEMENTATION OF ACUTE ISCHEMIC STROKE CASES IN ANUTAPURA MUNICIPAL HOSPITAL PALU
}

\author{
Diah Mutiarasari ${ }^{1}$, Rizaldy Taslim Pinzon ${ }^{2}$, Gunadi ${ }^{3}$ \\ ${ }^{1}$ The Graduate School of Medical Faculty of Gadjah Mada University \\ ${ }^{2}$ Medical Faculty of Duta Wacana Christian University \\ ${ }^{3}$ Surgery Departement of Medical Faculty of Gadjah Mada University
}

Correspondence:ms.diah@yahoo.com

\begin{abstract}
Background: Stroke has high mortality and disability rates. Stroke is the number one cause of death in hospital admission. The usage of clinical pathway can reduce variation in medical action for similar clinical condition, thus improving the quality of stroke treatment. Study on the development of clinical pathway by Integrated Clinical Pathway Appraisal Tools (ICPAT) in Indonesia is very limited.

Aim: This study was aimed to evaluate development and implementation processes of clinical pathway of acute ischemic stroke cases in RS Anutapura of Palu.

Method: The research design was action research. Data collection was performed by triangulation method using structures interview, focused group discussion, survey, observation, and document analysis. Integrated Clinical Pathway Appraisal Tools (ICPAT) used as a measuring tool. The research subjects were 25 respondents from health workers of $R S$ Anutapura and clinical pathway team, 1 respondent from patient's family, and 30 patients hospitalized in the neurological department of $R S$ Anutapura, who met eligibility criteria.

Result: The development process of evaluation result using ICPAT showed dimension 1 met overall requirements. Dimension 1 gave certainty that the developed document was clinical pathway. In the implementation process of clinical pathway, an evaluation of clinical pathway trial on acute ischemic stroke since patient was admitted to hospital until patient was released from hospital. The assessed indicators of service process 100\% EKG examination, 100\% ability to swallow, 100\% administration of antiplatelet (80 $\mathrm{mg}$ aspirin or $75 \mathrm{mg}$ clopidogrel) 24-48 hours since admission to hospital, 46,7\% administration of antiplatelet (325mg aspirin or $300 \mathrm{mg}$ clopidogrel) 24-48 hours since admission to hospital and $100 \%$ nutritional status assessment and stroke diet. Compliance to fill the clinical pathway of doctors and case managers was $80 \%$.

Conclusion: Based on new clinical pathway evaluation of acute ischemic stroke, there was compliance with ICPAT. The synergy of the entire hospital management, clinical champion, neurologists and multidisciplinary team was the key to successful development and implementation of clinical pathway.
\end{abstract}

Keywords: clinical pathway, ICPAT, stroke, action research. 


\section{PENDAHULUAN}

Era Jaminan Kesehatan Nasional (JKN), Badan Penyelenggara Jaminan Sosial (BPJS) ditunjuk sebagai lembaga yang menyelenggarakan sistem pelayanan kesehatan dengan kerangka kendali mutu dan kendali biaya sehingga menghasilkan pelayanan kesehatan yang bermutu dengan biaya yang efisien. Salah satu program mutu pelayanan di rumah sakit dengan melaksanakan program patient safety yang mengacu pada standar Joint Commicion International (JCI), yakni dengan menggunakan clinical pathway untuk meningkatkan mutu dan keselamatan pasien. ${ }^{1,2}$

Clinical pathway dapat didefinisikan sebagai pendekatan multidisiplin berbasis bukti yang menjelaskan tahapan-tahapan penting dalam memberikan pelayanan terhadap pasien. ${ }^{3}$ Penerapan clinical pathway dapat meningkatkan kualitas pelayanan, sehingga diharapkan di setiap rumah sakit dapat melaksanakan clinical pathway yang sesuai standar yaitu clinical pathway yang disusun dengan menggunakan Integrated Clinical Pathway Appraisal Tools (ICPAT). Pemberlakuan clinical pathway ternyata mampu menurunkan lama rawat inap, menurunkan angka komplikasi medis, memperbaiki proses dokumentasi, dan menurunkan biaya perawatan. ${ }^{4}$ Mengevaluasi dampak clinical pathway, maka terlebih dahulu melakukan standarisasi terhadap formulir clinical pathway. ${ }^{5}$

Pemilihan topik untuk sebuah clinical pathway haruslah sebuah kondisi klinik yang memiliki syarat sebagai berikut: high volume/ kasus terbanyak, high risk/ pelayanan berisiko tinggi, high cost/ berbiaya tinggi, problem prone/ mudah menimbulkan masalah dan multidisciplinary/ melibatkan banyak bagian yang terlibat aktif dalam penanganan pasien. ${ }^{6}$ Penyakit stroke dipilih karena mendukung syaratsyarat clinical pathway. Stroke memiliki angka kematian dan kecacatan yang tinggi. Di Negara maju stroke menjadi penyebab nomor 1 admisi pasien ke rumah sakit, dengan proporsi kematian sebanyak $20 \%$ dalam 28 hari pertama perawatan. ${ }^{7}$ Berdasarkan data Riset Kesehatan Dasar (Riskesdas) Tahun 2013 bahwa prevalensi stroke di Sulawesi Tengah sebesar 16,6\%o lebih tinggi dibandingkan prevalensi stroke di Indonesia 12,1\%o. ${ }^{8}$

Penelitian ini bertujuan untuk untuk melakukan evaluasi terhadap proses pengembangan dan penerapan clinical pathway dengan menggunakan instrumen yang sesuai standar dan telah divalidasi yaitu Integrated Clinical Pathway Appraisal Tools (ICPAT), sehingga diharapkan clinical pathway yang dijalankan bukan hanya sesuai standar, namun juga dengan kualitas terbaik dan dapat memberikan kontribusi yang bermakna terhadap peningkatan indikator mutu proses pelayanan di RS Anutapura untuk mewujudkan sistem pelayanan stroke yang terorganisir dan berkualitas sehingga memenuhi kepuasaan pasien.

\section{METODE PENELITIAN}

Penelitian ini menggunakan disain penelitian action research. Disain penelitian ini dipilih karena bersifat partisipatif. Penelitian melibatkan secara aktif subyek penelitian dalam proses pengembangan dan penerapan clinical pathway stroke iskemik akut. Pada penelitian ini, peneliti berfungsi sebagai fasilitator bagi tim multidisiplin pengembang clinical pathway. Studi dilaksanakan di RS Anutapura Kota Palu pada bulan April - September 2016.

Pengumpulan data dilakukan dengan triangulasi metode melalui 
wawancara terstruktur, diskusi kelompok terarah, survei, observasi, dan telaah dokumen. Penilaian kesesuaian clinical pathway pada proses pengembangan dan penerapan dengan menggunakan instrumen yang sudah divalidasi yaitu Integrated Clinical Pathway Appraisal Tools (ICPAT).

Subyek penelitian sebanyak 25 responden petugas kesehatan RS Anutapura yang terdiri dari Wakil Direktur Pelayanan, Kepala Bidang Pelayanan Medis, Kepala Bidang Anggaran dan Program, Kepala Bidang Keperawatan, Ketua Komite Medik, Kepala Instalasi IGD dan tim clinical pathway, 1 responden keluarga pasien dan 30 responden pasien yang dirawat inap di bagian saraf RS Anutapura berdasarkan kriteria inklusi dan eksklusi. Kriteria Inklusi adalah: 1) pasien baru dengan diagnosis utama stroke iskemik onset $<24$ jam, 2) usia pasien $>18$ tahun, 3) pasien yang dirawat inap dengan penggunaan clinical pathway dan 4) pasien dengan serangan pertama. Kriteria Eksklusi adalah 1) pasien rujukan, 2) pasien pulang paksa, dan 3) pasien dirawat di Intensive Care Unit (ICU).

Pengambilan sampel dilakukan dengan cara pengambilan sampel non probabilistik yakni purposive sampling. Analisis data pada penelitian ini dilakukan dengan menggunakan analisis kualitatif dan analisis kuantitatif.

\section{HASIL PENELITIAN}

Responden kualitatif pada penelitian ini terbagi 2 kelompok yaitu petugas kesehatan RS Anutapura sebanyak 22 orang dan pasien atau keluarga pasien sebanyak 31 orang. Responden kualitatif petugas kesehatan RS Anutapura terdiri dari laki-laki 5 $(22,7 \%)$ dan perempuan 17 (77,3\%). Berdasarkan usia, jumlah terbanyak responden berusia 31-50 tahun, yaitu 14 responden (63,6\%). Responden kualitatif pasien atau keluarga pasien terdiri dari laki-laki 9 (29\%) dan perempuan 22 (71\%). Berdasarkan usia, jumlah terbanyak responden berusia 46-60 tahun, yaitu 16 responden $(51,6 \%)$.

Responden kuantitatif adalah petugas kesehatan RS Anutapura Palu sebanyak 10 orang yang akan disurvei menggunakan kuesioner dengan tujuan untuk mengetahui tingkat pemahaman dan penerimaan terhadap clinical pathway. Responden kuantitatif petugas kesehatan RS Anutapura terdiri dari laki-laki 3 (30\%) dan perempuan 7 (70\%). Berdasarkan usia, jumlah terbanyak responden berusia 31-50 tahun, yaitu 6 responden (60\%). Responden penelitian selain petugas kesehatan, tedapat 30 orang pasien rawat inap di bagian saraf RS Anutapura yang memenuhi kriteria inklusi dan eksklusi, dimana pasien tersebut terlibat pada proses pengembangan dan penerapan clinical pathway baru stroke iskemik akut.

Tabel 1. Karakteristik pasien stroke iskemik akut yang dirawat inap dengan menggunakan clinical pathway

\begin{tabular}{lc}
\hline Karakteristik & Penerapan clinical pathway (n=30) n (\%) \\
\hline Jenis kelamin & $17(56,7)$ \\
Laki-laki & $13(43,3)$ \\
Perempuan & \\
Kelompok usia & $2(6,7)$ \\
$18-45$ tahun & $17(56,7)$ \\
$46-60$ tahun & \\
\hline
\end{tabular}




\begin{tabular}{|c|c|}
\hline Karakteristik & Penerapan clinical pathway $(\mathrm{n}=30) \mathrm{n}(\%)$ \\
\hline $61-80$ tahun & $10(33,3)$ \\
\hline$>80$ tahun & $1(3,3)$ \\
\hline \multicolumn{2}{|l|}{ Penurunan kesadaran } \\
\hline Composmentis (GCS : 15) & $27(90)$ \\
\hline Somnolen (GCS : 13-14) & $3(10)$ \\
\hline Sopor (GCS : 9-12) & 0 \\
\hline \multicolumn{2}{|l|}{ Onset } \\
\hline$<3$ jam & $5(16,7)$ \\
\hline $3-6$ jam & $4(13,3)$ \\
\hline $6-12$ jam & $8(26,7)$ \\
\hline $12-24$ jam & $13(43,3)$ \\
\hline \multicolumn{2}{|l|}{ Wajah perot } \\
\hline $\mathrm{Ya}$ & $24(80)$ \\
\hline Tidak & $6(20)$ \\
\hline \multicolumn{2}{|l|}{ Afasia/disatria } \\
\hline $\mathrm{Ya}$ & $22(73,3)$ \\
\hline Tidak & $8(26,7)$ \\
\hline \multicolumn{2}{|l|}{ Parese anggota gerak } \\
\hline Kanan & $15(50)$ \\
\hline Kiri & $10(33,3)$ \\
\hline Tidak ada parese & $5(16,7)$ \\
\hline \multicolumn{2}{|l|}{ Faktor risiko } \\
\hline Hipertensi & $24(80)$ \\
\hline Diabetes & $8(26,7)$ \\
\hline Merokok & $14(46,7)$ \\
\hline Dislipidemia & $15(50)$ \\
\hline Penyakit jantung & 3 (10) \\
\hline Obesitas & $10(33,3)$ \\
\hline \multicolumn{2}{|l|}{ Kelas perawatan } \\
\hline VVIP/VIP & $9(30)$ \\
\hline I & $4(13,3)$ \\
\hline II & $1(3,3)$ \\
\hline III & $16(53,3)$ \\
\hline
\end{tabular}

Tabel menunjukkan jumlah responden kuantitatif dengan karakteristik pasien stroke iskemik akut berdasarkan jenis kelamin terbanyak adalah laki-laki, yaitu 17 responden (56,7\%). Berdasarkan usia, jumlah terbanyak responden berusia 46-60 tahun, yaitu 17 responden $(56,7 \%)$.

\section{Kesesuaian Clinical Pathway Stroke Iskemik Akut dengan ICPAT}

Integrated Care Clinical Pathways Appraisal Tools (ICPAT) merupakan instrumen yang digunakan peneliti untuk menilai kesesuaian clinical pathway stroke iskemik akut yang telah diterapkan di RS Anutapura. Hasil evaluasi dapat dilihat sebagai berikut: 
Tabel 2. Dimensi ICPAT

\begin{tabular}{|c|c|c|c|c|}
\hline & \multicolumn{2}{|c|}{ Clinical Pathway Lama } & \multicolumn{2}{|c|}{ Clinical Pathway Baru } \\
\hline & Konten (\%) & Mutu (\%) & Konten (\%) & Mutu (\%) \\
\hline Dimensi 1 & 40 & 0 & 100 & 100 \\
\hline Dimensi 2 & 0 & 0 & 95,6 & 100 \\
\hline Dimensi 3 & 7,7 & 0 & 100 & 94,1 \\
\hline Dimensi 4 & 20 & 0 & - & - \\
\hline Dimensi 5 & 0 & 0 & _ & _ \\
\hline Dimensi 6 & 33,3 & 8,3 & 100 & 91,6 \\
\hline
\end{tabular}

Dimensi 1: Apakah benar clinical pathway? Berdasarkan hasil evaluasi terhadap clinical pathway lama yang telah diterapkan sejak tahun 2013 di RS Anutapura dengan menggunakan ICPAT pada dimensi 1 tentang identifikasi clinical pathway didapatkan bahwa hasil perbandingan clinical pathway lama dan clinical pathway baru terdapat peningkatan kesesuaian konten clinical pathway lama $40 \%$ menjadi $100 \%$ pada clinical pathway baru, sedangkan kesesuaian mutu terdapat peningkatan clinical pathway lama $0 \%$ menjadi 100\% pada clinical pathway baru.

Dimensi 2: Dokumentasi clinical pathway. Berdasarkan hasil evaluasi terhadap clinical pathway dengan menggunakan ICPAT pada dimensi 2 tentang dokumentasi clinical pathway didapatkan bahwa hasil perbandingan clinical pathway lama dan clinical pathway baru terdapat peningkatan kesesuaian konten clinical pathway lama 0\% menjadi $95,6 \%$ pada clinical pathway baru, sedangkan kesesuaian mutu terdapat peningkatan clinical pathway lama 0\% menjadi 100\% pada clinical pathway baru.

Dimensi 3: Proses pengembangan clinical pathway. Berdasarkan hasil evaluasi terhadap clinical pathway dengan mengguna kan ICPAT pada dimensi 3 tentang proses pengembangan clinical pathway didapatkan bahwa hasil perbandingan clinical pathway lama dan clinical pathway baru terdapat peningkatan kesesuaian konten clinical pathway lama $7,7 \%$ menjadi 100\% pada clinical pathway baru, sedangkan kesesuaian mutu terdapat peningkatan clinical pathway lama 0\% menjadi $94,1 \%$ pada clinical pathway baru.

Dimensi 6: Peran organisasi terhadap clinical pathway. Berdasarkan hasil evaluasi terhadap clinical pathway dengan menggunakan ICPAT pada dimensi 6 tentang peran organisasi terhadap clinical pathway didapatkan bahwa hasil perbandingan clinical pathway lama dan clinical pathway baru terdapat peningkatan kesesuaian konten clinical pathway lama 33,3\% menjadi $100 \%$ pada clinical pathway baru, sedangkan kesesuaian mutu terdapat peningkatan clinical pathway lama $8,3 \%$ menjadi $91,6 \%$ pada clinical pathway baru.

\section{Proses Pengembangan dan Penerapan Clinical Pathway \\ a. Proses pengembangan clinical pathway}

Proses pengembangan Panduan Praktik Klinis (PPK) dan clinical pathway kasus stroke iskemik akut diselesaikan dalam jangka waktu 4 minggu, dimana peneliti berperan sebagai fasilitator. Panduan Praktik Klinis (PPK) dan clinical pathway disusun tim multidisiplin yang dikoordinasikan dengan Komite Medis.

Tahapan proses pengembangan diawali dengan adanya keputusan pimpinan RS Anutapura untuk mengembangkan PPK dan clinical pathway yang sesuai standar. 
Clinical champion berperan sebagai koordinator program tim pengembangan clinical pathway baru kasus stroke iskemik akut adalah kepala SMF saraf. Koordinator tim tersebut bertugas membentuk tim pengembang clinical pathway yang memiliki komitmen pada proses perubahan, memotivasi, mendukung tim, memastikan penggunaan evidence based best practice, dan terlibat aktif dalam proses pengembangan clinical pathway.

Tim pengembang clinical pathway tersebut terdiri dari dokter spesialis saraf, dokter umum, perawat, apoteker/ farmasi klinik, nutritionist, fisioterapis, petugas rekam medis dan petugas laboratorium. Melaksanakan workshop pengembangan dan penerapan clinical pathway yang dihadiri oleh manajemen RS Anutapura dan tim pengembangan clinical pathway dan dilakukan dengan beberapa kali pertemuan lanjutan sehingga menghasilkan draft sementara PPK dan clinical pathway. Konsensus dilakukan dengan seluruh tim clinical pathway di ruang rapat komite medik selama \pm 5 jam. Hasil konsensus tersebut menghasilkan PPK dan clinical pathway yang akan disosialisasikan dan dilakukan penerapan uji coba. Pada proses pengembangan clinical pathway baru stroke iskemik akut melibatkan perwakilan salah satu keluarga pasien untuk mereview clinical pathway dalam hal memastikan kerahasiaan pasien.

\section{b. Proses penerapan uji coba clinical pathway}

Pada proses penerapan clinical pathway dilakukan uji coba untuk melihat kemampuan pelaksanaan clinical pathway. Sosialisasi dilakukan peneliti sebelum uji coba penerapan clinical pathway. Hasil sosialisasi adalah respon positif dari semua pihak yang terlibat, juga terdapat masukan yang diberikan dalam hal tekhnis untuk penerapan uji coba. Edukasi juga dilakukan peneliti saat uji coba dengan cara mendatangi langsung ke IGD atau ruang perawatan pasien stroke iskemik akut yang menggunakan clinical pathway.

Clinical pathway stroke iskemik akut di bagian saraf RS Anutapura menjalani masa penerapan uji coba sejak bulan Mei sampai September 2016 dengan jumlah sampel uji coba sebanyak 30 pasien dan selama proses uji coba pelaksanaannya dibantu oleh case manager. Dokter spesialis saraf berperan sebagai clinical leader dalam proses pelayanan asuhan medis pasien stroke iskemik akut yang disebut Dokter Penanggung Jawab Pelayanan (DPJP). Pada penerapan uji coba clinical pathway stroke iskemik, DPJP, case manager, perawat, dan pemberi asuhan lainnya berkolaborasi menjaga kontinuitas pelayanan sejak pasien masuk RS sampai pemulangan.

Penerapan clinical pathway dapat digunakan sebagai salah satu alat evaluasi penilaian variasi dalam rangka meningkatkan mutu dan keselamatan pasien. Selama penerapan uji coba clinical pathway, terdapat variasi dalam pelayanan. Analisis variasi dilakukan oleh peneliti dan tim clinical pathway pada saat penerapan uji coba.

\section{Evaluasi Clinical Pathway \\ a. Proses pelayanan}

Indikator proses pelayanan yang dinilai pada pelayanan pasien stroke iskemik sejak pasien masuk ke IGD sampai ke ruang perawatan. 
Tabel 3. Indikator proses pelayanan penerapan clinical pathway baru

\begin{tabular}{lc}
\hline \multicolumn{1}{c}{ Indikator Proses } & $\begin{array}{c}\text { Penerapan clinical } \\
\text { pathway (n=30) } \\
\mathbf{n}(\mathbf{\%})\end{array}$ \\
\hline $\begin{array}{l}\text { EKG dikerjakan pada saat masuk RS } \\
\text { Penilaian kemampuan menelan pada saat masuk RS }\end{array}$ & $30(100)$ \\
$\begin{array}{l}\text { Anti platelet (Aspirin 80mg atau Clopidogrel 75mg) } \\
\text { diberikan 24-48 jam sejak masuk RS }\end{array}$ & $30(100)$ \\
$\begin{array}{l}\text { Anti platelet (Aspirin 325mg atau Clopidogrel 300mg) } \\
\text { diberikan 24-48 jam sejak masuk RS }\end{array}$ & $14(46,7)$ \\
Penilaian status gizi dan diet stroke seawal mungkin & $30(100)$ \\
\hline
\end{tabular}

\section{b. Luaran pasien}

Saat penerapan uji coba dilakukan audit outcome pasien yang harus dicapai. Sebelum pasien keluar dari RS berupa penilaian defisit neurologis dengan National Institute of Health Stroke Scale (NIHSS), penilaian status fungsional (Modified Rankin Scale) dan lama hari rawat.

Tabel 4. Indikator luaran penerapan clinical pathway baru (\%)

\begin{tabular}{lc}
\multicolumn{1}{c}{ Indikator Luaran } & $\begin{array}{c}\text { Penerapan clinical } \\
\text { pathway (n=30) } \mathbf{n}(\%)\end{array}$ \\
\hline National Institutes of Health Stroke Scale (NIHSS) & $19(63,3)$ \\
$<5$ (defisit neurologi ringan) & $10(33,3)$ \\
$6-14$ (defisit neurologi sedang) & $1(3,3)$ \\
$15-24$ (defisit neurologi berat) & 0 \\
> 25 (defisit neurologi sangat berat) & \\
Modified Rankin Scale (MRS) & 0 \\
Tidak ada gejala & $12(40)$ \\
Tidak ada disabilitas, terdapat gejala minimal & $4(13,3)$ \\
Disabilitas ringan & $1(3,3)$ \\
Disabilitas sedang & $7(23,3)$ \\
Disabilitas sedang berat & $6(20)$ \\
Disabilitas berat & 0 \\
Meninggal & \\
Lama hari rawat & $15(50)$ \\
< 7 hari & $6(20)$ \\
7 hari & $9(30)$ \\
> 7 hari &
\end{tabular}

Lama hari rawat merupakan salah satu indikator luaran pasien. Rerata lama hari rawat adalah 6,7 hari $\pm 2,5$ hari (rentang 3-16 hari) untuk keseluruhan pasien stroke iskemik yang menggunakan clinical pathway.

c. Kepatuhan pengisian clinical pathway

Kepatuhan pengisian clinical pathway pada penelitian ini adalah penilaian kelengkapan pengisian clinical pathway baru stroke iskemik akut sesuai Panduan Praktik Klinis (PPK) oleh dokter dan case manager. Berdasarkan hasil penelitian bahwa tingkat kepatuhan pengisian clinical pathway baru pada pasien stroke iskemik akut di bagian saraf RS Anutapura sebesar $80 \%$, adapun tidak patuh sebesar 20\% karena adanya variasi yang timbul selama proses perawatan pasien. 


\section{d. Faktor hambatan dan faktor pendukung pengembangan dan penerapan clinical pathway}

Pada penelitian ini terdapat faktor hambatan dan faktor pendukung selama proses pengembangan dan penerapan clinical pathway dilakukan. Faktor hambatan adalah belum optimalnya kinerja case manager, case management system belum diterapkan dengan baik, ketersediaan sumber daya masih kurang, dan belum adanya program pelatihan komprehensif terkait penggunaan clinical pathway sehingga mempengaruhi lancarnya proses pengembangan dan penerapan uji coba clinical pathway stroke iskemik di RS Anutapura.

Faktor pendukung dalam proses pengembangan dan penerapan uji coba clinical pathway baru stroke iskemik akut adalah dukungan pihak manajemen RS dan terutama dukungan clinical champion RS sebagai koordinator tim clinical pathway serta tim multidisiplin clinical pathway sehingga sangat mempengaruhi perubahan budaya dalam memberikan pelayanan dengan menggunakan clinical pathway di RS Anutapura khususnya pada bagian saraf. Pada beberapa pertemuan clinical champion menyakinkan bahwa clinical pathway mempunyai banyak manfaat jika diterapkan dengan baik di pelayanan, utamanya dapat meningkatkan outcome pasien sehingga dapat mengubah persepsi dokter mengenai clinical pathway dan tidak menolak untuk menggunakan clinical pathway dan memiliki komitmen untuk meningkatkan mutu pelayanan dan keselamatan pasien serta meningkatkan kepercayaan masyarakat terhadap RS Anutapura. Disain clinical pathway yang dibuat tidak terlalu rumit, mudah dimengerti oleh petugas yang mengisi clinical pathway, cara pengisian dengan mencontreng sehingga tidak menambah beban kerja petugas.

\section{PEMBAHASAN}

\section{Kesesuaian Clinical Pathway Stroke Iskemik Akut dengan ICPAT}

Hasil evaluasi kesesuaian clinical pathway baru stroke iskemik dengan ICPAT berdasarkan hasil self assessment dimensi 1 dapat dipastikan bahwa dokumen clinical pathway yang dikembangkan bagian saraf RS Anutapura adalah benar sebuah clinical pathway. Temuan penelitian Whittle yang menyatakan bahwa clinical pathway seyogyanya memenuhi seluruh item pada dimensi 1 karena dianggap dokumen tersebut bersifat kohesif dan multidisiplin. Temuan ini memiliki implikasi yang penting bagi banyak lembaga layanan kesehatan yang telah menggunakan clinical pathway secara terencana guna mewujudkan perawatan teratur, efektif, berbasis bukti dan berkesinambungan. ${ }^{9}$

\section{Proses Pengembangan dan Penerapan Clinical Pathway \\ a. Pengembangan pathway}

Rumah sakit dalam melaksanakan fungsinya, sebaiknya dapat meminimalkan risiko yang mungkin terjadi selama proses pelayanan kesehatan berlangsung sehingga pelayanan bermutu tinggi sebagai salah satu tujuan utama dari sistem kesehatan nasional dapat tercapai. Upaya peningkatan mutu di RS dapat dilaksanakan secara efektif melalui clinical governance, yang meliputi adanya komitmen, meningkatkan mutu pelayanan dan asuhan pasien secara berkesinambungan, memberikan pelayanan dengan pendekatan yang berfokus pada pasien, dan mencegah clinical medical error. Mengurangi adanya variasi dalam tindakan medis untuk kondisi klinis yang sama merupakan cara yang 
paling efektif dalam meningkatkan mutu pelayanan di RS. Pelayanan kesehatan dengan clinical governance mempunyai kerangka kerja mempertahankan dan meningkatkan mutu pelayanan, namun dapat dilakukan ketika infrastruktur RS memberikan dukungan kuat baik aspek klinis maupun non klinis. 10,11,12

Clinical pathway baru stroke iskemik akut telah melewati 7 dari 8 tahapan dalam proses pengembangan clinical pathway. Tahapan yang belum dilakukan pada penelitian ini berdasarkan guideline menurut Davis et al yaitu melakukan review clinical pathway secara teratur ketika penerapan penuh telah dilakukan. ${ }^{13}$ Pengembangan PPK dan clinical pathway merupakan proses panjang dan intensif yang disusun berdasarkan bukti ilmiah dan disesuaikan dengan kondisi RS. Temuan ini sesuai dengan penelitian Siebens et al bahwa pengembangan clinical pathway merupakan proses yang melelahkan dan rutin dimana petugas kesehatan yang heterogen harus dimotivasi untuk berpartisipasi aktif dan mengubah praktik pelayanan yang ada. ${ }^{14}$

Pengembangan clinical pathway baru stroke iskemik melibatkan tim multidisiplin RS Anutapura. Penelitian Roymeke dan Stummer bahwa pengembangan clinical pathway oleh penyedia layanan melibatkan banyak kelompok profesional yakni dokter, perawat, terapis dan staf lainnya. ${ }^{15}$ Penelitian Huang et al menunjukkan pengembangan clinical pathway memberikan koordinasi pelayanan bagi pengguna clinical pathway dengan tujuan untuk memiliki "orang" yang tepat, melakukan hal yang benar, melakukan tindakan dengan tahapan yang benar, pada waktu yang tepat, di tempat yang tepat, dengan hasil yang tepat. ${ }^{16}$

\section{b. Penerapan clinical pathway}

Pelaksanaan workshop pengembangan dan penerapan clinical pathway dengan melibatkan staf klinis dan manajemen merupakan salah satu kunci keberhasilan sebelum melakukan proses penerapan clinical pathway yang berhasil. ${ }^{1}$ Clinical pathway sebaiknya dapat mengakomodir adanya variasi dalam penerapan clinical pathway, sehingga clinical pathway sebaiknya bersifat fleksibel dalam penggunaannya. Sebuah clinical pathway harus mampu mengantisipasi timbulnya variasi $20-40 \%$ dari populasi pasien. ${ }^{10}$

Variasi dalam penerapan clinical pathway dapat digunakan sebagai alat untuk melakukan audit medis dan manajemen sehingga dapat menjaga dan meningkatkan mutu pelayanan. ${ }^{10}$

\section{Evaluasi Clinical Pathway}

\section{a. Proses pelayanan}

Evaluasi clinical pathway dalam penerapan clinical pathway sebaiknya dilakukan secara rutin dan berkelanjutan. Clinical pathway merupakan instrumen manajemen strategis yang berfungsi sebagai alat pengendalian biaya dan dapat berkontribusi dalam transparansi melakukan penyediaan layanan. Sistem pelayanan kesehatan yang baik dapat melakukan pemantauan proses pelayanan dan luaran (outcome) secara berkala. ${ }^{15}$

Clinical pathway menunjukkan bahwa adanya perbaikan dalam proses pelayanan sehingga mempengaruhi luaran pasien stroke. Proses yang baik meliputi visite oleh dokter konsultan < 24 jam pasca admisi, pemeriksaan CT Scan dalam waktu 24 jam pasca admisi, fisioterapi dalam waktu 72 jam pasca admisi, pasien yang datang dengan onset kurang dari 4 jam dirawat di unit stroke multidisiplin, pemberian antiplatelet sesegera mungkin dan 
esesmen fungsi menelan dan kebutuhan nutrisi. ${ }^{17}$

\section{b. Luaran Pasien}

Luaran klinis pasien stroke akut dinilai berdasarkan National Institutes of Health Stroke Scale (NIHSS). Indikator luaran pasien stroke umumnya digambarkan pada status fungsional pasca serangan, angka kematian dan lama hari perawatan pasien stroke. Status fungsional dinilai dengan skala Rankin yang dimodifikasi. ${ }^{18}$

Beberapa penelitian membuktikan efektif dan efisien sebuah clinical pathway dalam memperbaiki luaran klinis sebagai kondisi penyakit. Penerapan clinical pathway dapat menurunkan angka kematian pada 7 hari perawatan di RS $(O R=0,10$, 95\% CI: 0,01-0,95). Rata-rata lama hari perawatan pada penelitian ini adalah 6,7 hari untuk keseluruhan pasien stroke iskemik yang menggunakan clinical pathway. ${ }^{7}$ Penelitian Huang et al menyatakan bahwa rerata lama hari perawatan pasien yang di rawat inap menggunakan clinical pathway lebih pendek lama hari perawatan dibandingkan dengan pasien yang dirawat inap tanpa menggunakan clinical pathway dan tingkat kepuasaan pasien terlihat lebih tinggi pada pasien yang meng-gunakan clinical pathway. ${ }^{16}$

\section{c. Kepatuhan pengisian clinical pathway}

Kepatuhan dokter dan case manager dalam melakukan pengisian clinical pathway baru stroke iskemik di RS Anutapura mencapai $80 \%$. Pencapaian ini berhasil karena adanya kolaborasi multidisiplin profesi (dokter, case manager, perawat, dan staf pendukung lain). Case manager diharapkan membantu kelancaran pengisian clinical pathway, kepatuhan terhadap clinical pathway, dan memudahkan analisis varian dan proses audit.
Case manager mempunyai peran sangat penting dalam mengawasi jalannnya clinical pathway. ${ }^{10,19}$

\section{d. Faktor hambatan dan faktor pendukung proses pe- ngembangan dan penerapan clinical pathway}

Pada penelitian ini didapatkan faktor hambatan yang berhubungan dengan penerapan uji coba clinical pathway adalah belum optimalnya kinerja case manager, case management system belum diterapkan dengan baik, ketersediaan sumber daya masih kurang, dan belum adanya program pelatihan komprehensif terkait penggunaan clinical pathway sehingga mempengaruhi lancarnya proses pengembangan dan penerapan uji coba clinical pathway. Temuan hasil penelitian Cheah bahwa case manager ditugaskan bertindak sebagai fasilitator dan evaluator yang berperan untuk melakukan pengawasan ketat dalam pengisian dan penerapan clinical pathway pada masa uji coba. ${ }^{10}$ Temuan hasil penelitian Evans-Lacko et al bahwa kunci keberhasilan dalam uji coba clinical pathway adanya case manager yang memantau dan memastikan clinical pathway dapat berjalan dengan baik. Sumber daya dan fasilitas yang tersedia, kurangnya pelatihan terkait penggunaan pathway, pergantian staf RS, kurangnya kesadaran, kurangnya evaluasi dan feedback dapat menyebabkan kegagalan implementasi care pathway. ${ }^{1}$

Faktor pendukung dalam proses pengembangan dan penerapan uji coba clinical pathway baru stroke iskemik akut adalah sinergi seluruh manajemen RS, adanya clinical champion RS dan keterlibatan aktif tim multidisiplin. Temuan hasil penelitian Evans-Lacko, et al bahwa kunci keberhasilan dalam penggunaan clinical pathway ini terletak 
pada kemampuan berkoordinasi secara lintas disiplin ilmu. ${ }^{1}$

\section{KESIMPULAN}

Evaluasi clinical pathway baru stroke iskemik akut me-nunjukkan kesesuaian dengan dimensi pada ICPAT. Sinergi seluruh manajemen RS, clinical champion, dokter spesialis saraf dan tim multidisiplin menjadi kunci ke-berhasilan pengembangan dan penerapan clinical pathway.

\section{DAFTAR PUSTAKA}

1. Evans-Lacko, S., Jarret, M., McCrone, P., et al. Facilitators and barriers to implementing clinical care pathways. BMC Health Services Research. $2010 ; 10,182$

2. Joint Commission International Accreditation Standards For Hospitals. Health Care Organization Management Standards: Quality Improvement and Patient Safety (QPS). USA:Joint Commission Resources; 2013

3. Rotter, T., Kinsman, L., James, E., et al. The quality of the evidence base for clinical pathway effectiveness : Room for improvement in the design of evaluation trials. BMC Medicine. 2012;12(80)

4. Rotter, T., Kinsman, L., James, E., et al. Clinical pathways : effect on professional practice, patient outcomes, length of stay and hospital costs. Cochrane Database Syst Rev. 2010;3,CD006632

5. Kinsman, L., Rotter, T., James, E., et al. What is clinical pathway? Development of definition to inform debate. BMC Medicine. 2010;8,31

6. Curran, D., Browning, J., Bryett, A., et al. A Toolkit for developing a clinical pathway. Queensland Government; 2005
7. Panella, M., Marchisio, S., Brambilla, R., et al. A cluster randomized trial to assess the effect of clinical pathway $s$ for patients with stroke: results of the clinical pathway $s$ for effective and appropriate care study. BMC Medicine. 2012;10(71)

8. Badan Litbangkes RI. Riset Kesehatan Dasar (Riskesdas) Nasional 2013. Badan Penelitian Dan Pengembangan Kesehatan Kementerian Kesehatan RI, Jakarta; 2013

9. Whittle, C. ICPAT : Integrated Care Pathway Appraisal Tools. International Journal of Care Pathways. 2009;13,75-77

10. Cheah, J. Development and implementation of a clinical pathway program in an acute care general hospital in Singapore. International Journal for Quality in Healthcare. 2000;12(5), 40312

11. McSherry, R., and Pearce, P. Clinical Governance: A Guide to Implementation for Healthcare Professionals, $3^{\text {rd }}$ ed, Chichester: Wiley-Blackwell; 2011

12. Komisi Akreditasi Rumah Sakit. Panduan Pelaksanaan Dokter Penanggungjawab Pelayanan (DPJP) dan Case Manager, Jakarta; 2015

13. Davis, N., Sansom, G., Jones, S., et al. Integrated care pathways a guide to good practice. Wales: National Leadership and Innovation Agency for Healthcare; 2005

14. Siebens, K., Miljoen, H., Geest, S., et al. Development and implementation of a critical pathway for patients with chest pain through action research. European Journal of Cardiovascular Nursing. 2012;11 (4), 466-71

15. Roymeke, $\mathrm{T}$ and Stummer, $\mathrm{H}$. Clinical pathways as instruments for risk and cost management in 
hospital - A discussion paper. Global Journal of Health Science. 2012;Vol 4. No.2 pp.50-59

16. Huang, Di., Song, X., Tian, J., Cui, Q., Yang, K. Effects of clinical pathway s in stroke management: A meta-analysis. Neurology Asia. 2015;Vol.20, No.4:335-342

17. Bray BD, Ayis S, Campbell J, et al. Associations between the organization of stroke services, process, of care, and mortality in England: Prospective Cohort Study. BMJ. 2013;346:2827

18. Harrison, J.K., McArthrur, K.S., Quinn, T.J. Assessment Scales in Stroke: Clinimetric and Clinical Consideration. Clinical Interventions in Aging. 2013; 8:201-11 